\title{
The social dimension of globalization: A review of the literature
}

\author{
Bernhard G. GUNTER* and Rolph van der HOEVEN **
}

Thestis he term globalization is used in many different contexts. Indeed, it has become a buzzword with a multitude of meanings and interpretations. In this literature review, however, globalization is taken to mean the gradual integration of economies and societies driven by new technologies, new economic relationships and the national and international policies of a wide range of actors, including governments, international organizations, business, labour and civil society. Some contributors to the literature have suggested distinguishing between specific facets of globalization (e.g. increased international trade) and parallel developments (e.g. technological advances); others have argued that a separation of interconnected processes is not feasible.

From a conceptual point of view, however, it is useful to split the globalization process into two parts. The first concerns factors such as trade, investment, technology, cross-border production systems, information flows and communication. Though all these factors have brought some economies and some societies closer together, they have also marginalized many countries and individuals. There is concern that because of an increasingly knowledge-driven world economy, more and more people will become marginalized, especially if the digital divide cannot be drastically reduced. The second aspect of the globalization process concerns the increased homogenization of policies and institutions across the world, e.g. trade and capital market liberalization; the dismantling of the welfare state; international agreements on intellectual property rights; and the standardization of policies and behaviours that

* Freelance consultant specializing in development macroeconomics, poverty and debt. Email: Bernhardgunter@earthlink.net.** Secretariat of the World Commission on the Social Dimension of Globalization (WCSDG), ILO. Email: hoeven@ilo.org. This article is based on a background paper prepared for the WCSDG. 
have promoted globalization. While the first aspect is irreversible, the second is not inevitable but the result of policy choices. Depending on which policies and international agreements are selected (such as the adoption of international core labour standards), ${ }^{1}$ influence can be brought to bear on the social impact of globalization. With sufficiently drastic policy changes, the current economic globalization process could be altered.

The social dimension of globalization relates to the impact of globalization on the life and work of people, their families, and their societies. Concern is often raised about the impact of globalization on employment, working conditions, income and social protection. Beyond the world of work, the social dimension includes security, culture and identity, inclusion or exclusion from society and the cohesiveness of families and communities. This literature review will consider the impact of economic globalization on wages and taxes, poverty, inequality, insecurity, child labour, gender and migration.

The intention of this survey is not to present the broad spectrum of contrasting views that exists in the literature, but to summarize some recent significant articles and publications on the various social dimensions of the economic globalization process and to suggest some key policy responses to make globalization a fairer and more sustainable process for all.

This literature review draws on over 1,200 articles and books collected for the World Commission on the Social Dimension of Globalization $^{2}$ and listed in the Commission's bibliography on the social impact of globalization (see Gunter (2004)). It is structured as follows. First, a brief review is made of the key economic characteristics of the globalization process, based on data for 1985-2002, which provides recent historical context. Different aspects of the social impact of the recent globalization process are then considered, summarized on the basis of the recent literature. Though considerable controversy still surrounds some of these aspects, a consensus does seem to be emerging on

\footnotetext{
${ }^{1}$ See Dølvik and Tørres (2002) and, for example, ILO (2004), pp. 91-95; ILO (2003); and ILO (1999).

2 The World Commission on the Social Dimension of Globalization was established by the International Labour Organization (ILO) in February 2002. The Commission was chaired by two heads of state, the President of Finland, Tarja Halonen, and the President of the United Republic of Tanzania, Benjamin Mkapa. The World Commission's goal is to examine ways in which national and international institutions and organizations can contribute to a more inclusive globalization process acceptable and fair to all. It represents an unprecedented effort to promote national and international dialogue on ideas to make globalization more inclusive, at a time when the debate is dominated by polemics and preconceptions rather than by facts. Ultimately, the aim is to use the process of globalization as a resource to reduce poverty and unemployment, and to foster growth and sustainable development. Its report $A$ fair globalization: Creating opportunities for all was published on $24 \mathrm{Feb} .2004$.
} 
others. Using this emerging consensus, the next section reviews a range of national and international policy responses proposed in the literature. Currently, there is broad agreement that some policy responses are needed to make globalization more sustainable and equitable and to deliver what working people and their families aspire to everywhere: a decent job, security and a voice in the decision-making process. Nevertheless, there is little agreement on the exact contents of such corrective policies. The last section offers some conclusions.

\section{Key economic characteristics}

The purpose here is to present some stylized facts of the economic characteristics of the recent globalization process, in order to understand the social impact of globalization better. First the increase in international trade is reviewed, touching upon some of the key policy factors involved: global reductions in both tariffs and non-tariff barriers. Then the growth in international capital transactions is considered, as these were encouraged by the increased removal of capital controls and of restrictions on foreign investment and foreign ownership of assets. Next, a brief review is made of the increase in international production, which is dominated by the multinational corporations' fragmentation of the production process. In so far as appropriate data are available, differences between low-, middle- and high-income countries are drawn out. This will provide some background on key asymmetries of recent economic globalization.

\section{International trade}

World trade (measured in terms of nominal world exports of goods and services) more than tripled from US $\$ 2,300$ billion in 1985 to over US $\$ 7,800$ billion in 2002 (table 1). During the same period, world nominal gross domestic product (GDP) increased by two and a half (from US $\$ 12,800$ billion in 1985 to US $\$ 32,100$ billion in 2002). A positive difference between the growth rate of world trade minus the growth rate of world GDP is defined as the speed of trade integration. The speed of integration varies across regions, with Latin America and East Asia slowing down and high-income OECD (Organisation for Economic Co-operation and Development) countries accelerating. However, the ratio of exports to GDP fell in about a third of the 174 countries (with sufficient data) between 1985 and 2002, reflecting trade disintegration. For 12 countries - all of them developing countries ${ }^{3}-$ the ratio fell more than 20 percentage points between 1985 and 2002.

3 Antigua and Barbuda, Bahrain, Botswana, Djibouti, Estonia, Kazakhstan, Kiribati, Lebanon, Macedonia, Mauritania, St. Vincent and the Grenadines, and Suriname. 
Table 1. Evolution of income, exports, and capital flows, 1985-2002

\begin{tabular}{|c|c|c|c|c|c|}
\hline & \multicolumn{2}{|l|}{ US\$ billion } & \multirow[t]{2}{*}{ Increase 1985-2002 } & \multicolumn{2}{|c|}{$\begin{array}{l}\text { Percentage share } \\
\text { of world level }\end{array}$} \\
\hline & 1985 & 2002 & & 1985 & 2002 \\
\hline \multicolumn{6}{|l|}{ Gross domestic product } \\
\hline China and India & 558.5 & 1922.4 & 3.4 fold increase & 4.4 & 6.0 \\
\hline Low-income countries, excl. India & 579.3 & 634.7 & 1.1 fold increase & 4.5 & 2.0 \\
\hline Middle-income countries, excl. China & 2234.1 & 3702.9 & 1.7 fold increase & 17.5 & 11.5 \\
\hline High-income countries & 9393.4 & 25867.0 & 2.8 fold increase & 73.6 & 80.5 \\
\hline World & 12765.2 & 32127.0 & 2.5 fold increase & 100.0 & 100.0 \\
\hline \multicolumn{6}{|l|}{ Exports of goods and services } \\
\hline China and India & 79.1 & 685.1 & 8.7 fold increase & 3.4 & 8.7 \\
\hline Low-income countries, excl. India & 82.5 & 215.2 & 2.6 fold increase & 3.6 & 2.7 \\
\hline Middle-income countries, excl. China & 433.9 & 1227.2 & 2.8 fold increase & 18.7 & 15.6 \\
\hline High-income countries & 1718.7 & 5732.6 & 3.3 fold increase & 74.3 & 72.9 \\
\hline World & 2314.1 & 7860.2 & 3.4 fold increase & 100.0 & 100.0 \\
\hline \multicolumn{6}{|l|}{ Inflows of foreign direct investment } \\
\hline China and India & 1.7 & 62.0 & 37.4 fold increase & 2.9 & 9.8 \\
\hline Low-income countries, excl. India & 1.9 & 7.1 & 3.7 fold increase & 3.3 & 1.1 \\
\hline Middle-income countries, excl. China & 9.7 & 79.1 & 8.1 fold increase & 16.8 & 12.5 \\
\hline High-income countries & 44.7 & 484.3 & 10.8 fold increase & 77.1 & 76.6 \\
\hline World & 58.0 & 632.6 & 10.9 fold increase & 100.0 & 100.0 \\
\hline \multicolumn{6}{|l|}{ Inflows of total portfolio investment } \\
\hline China and India & 2.3 & 49.8 & 22.0 fold increase & 1.7 & 6.9 \\
\hline Low-income countries, excl. India & 0.05 & 0.07 & 1.3 fold increase & 0.038 & 0.009 \\
\hline Middle-income countries, excl. China & 9.1 & 30.0 & 3.3 fold increase & 6.7 & 4.2 \\
\hline High-income countries & 123.8 & 639.9 & 5.2 fold increase & 91.6 & 88.9 \\
\hline World & 135.2 & 719.8 & 5.3 fold increase & 100.0 & 100.0 \\
\hline
\end{tabular}

Sources: Country classifications based on World Bank (2003a); data on GDP and exports of goods and services are taken from IMF (2003a); data on capital flows are taken from IMF (2003b). Data for 2002 may be preliminary for some countries.

Much of the increase in international trade is due to the liberalization of world trade. Until the early 1990s, developing countries generally had higher levels of protection than industrialized countries, as previously trade policy had been used to foster industrial development. With higher levels of protection it was also intended to avoid balance of payments crises. Comparison with the 1980s shows that, on average, developing countries' tariffs were about four times higher than those of industrialized countries. Non-tariff barriers (NTBs) of developing countries covered over twice the share of import categories than those covered by industrialized countries' NTBs. However, over the past ten 
years, many developing countries have liberalized their tariff regimes by simplifying tariff structures, reducing rates and sometimes also eliminating NTBs. In the early 1990s, the import growth of developing countries jumped to more than five times that of the early 1980s. Tariff liberalization went furthest in Latin America.

Between 1985 and 2002, exports of goods and services increased by multiples for all four country-groups: (a) China and India; (b) the low-income countries, excluding India; (c) the middle-income countries, excluding China; and (d) the high-income countries (see table 1, col. 3). The largest increase was that for China and India, followed by that for the high-income countries. The lowest increase was that for the lowincome countries, excluding India. Thus, over 17 years the share in world trade of the low-income countries (excl. India) actually decreased, from 3.6 per cent in 1985 to 2.7 per cent in 2002, implying a marginalization in terms of world trade (see table 1, last 2 cols.). Note that those countries' share in world GDP decreased even more drastically over the same period (from 4.5 per cent in 1985 to 2.0 per cent in 2002), reflecting an even stronger marginalization in terms of world income. Even the middle-income countries (excl. China) lost in terms of world market share of income and trade. High-income countries gained in terms of their share in world income, while experiencing a slight reduction in their share of world exports, reflecting the very sharp increase in the trade share of China and India.

When looking at these trade figures measured in US dollars, it is important to bear in mind that there have been considerable changes in the terms of trade, with the group of middle- and high-income countries experiencing increasing terms of trade, to the detriment of the lowincome countries (see figure 1). Thus, though the marginalization of most low-income countries would be less severe if trade volumes were considered, ${ }^{4}$ the declining terms of trade represent a formidable challenge for low-income countries.

Figures 2 and 3 show the annual changes in GDP and exports of goods and services, respectively, for the four country-groups considered, over the period 1985-2002. The marginalization of the lowincome countries is clear (shown as the thin line at the bottom of each figure).

${ }^{4}$ As Birdsall and Hamoudi (2002) have pointed out, owing to these price changes, it is inappropriate to use changes in the trade/GDP as a basis for classifying countries as "globalizers" or "non-globalizers". 
Figure 1. Terms of trade, 1985-2002

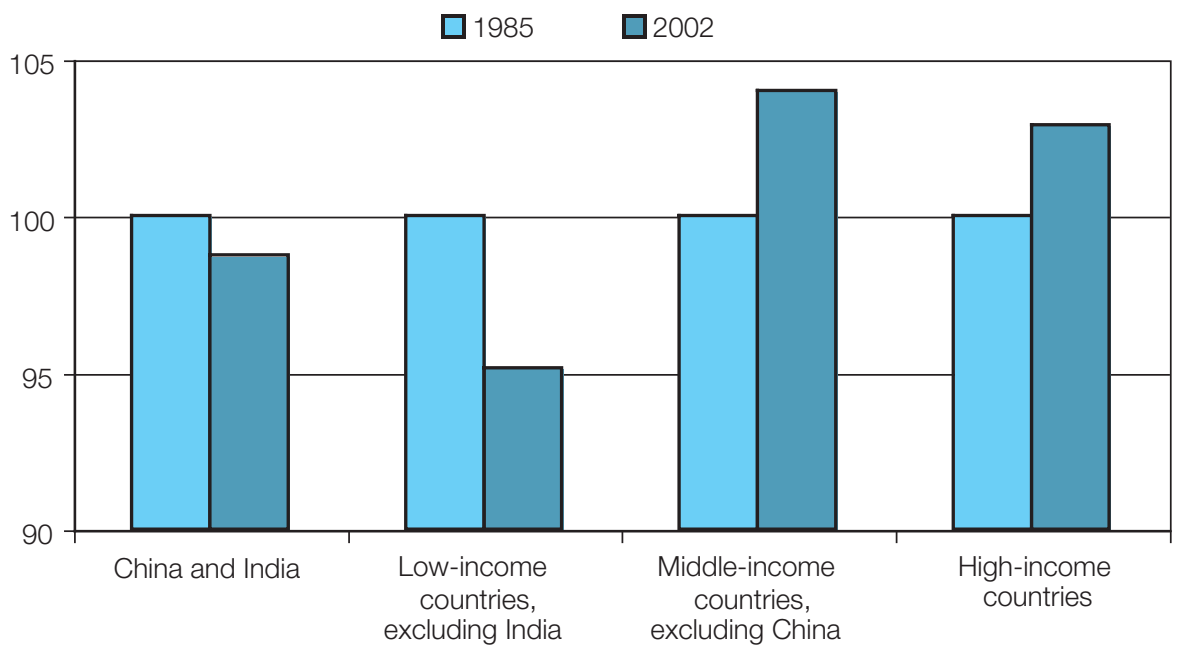

Sources: World Bank (2003b); and IMF (2003a).

Figure 2. Evolution of GDP (billions of current US\$)

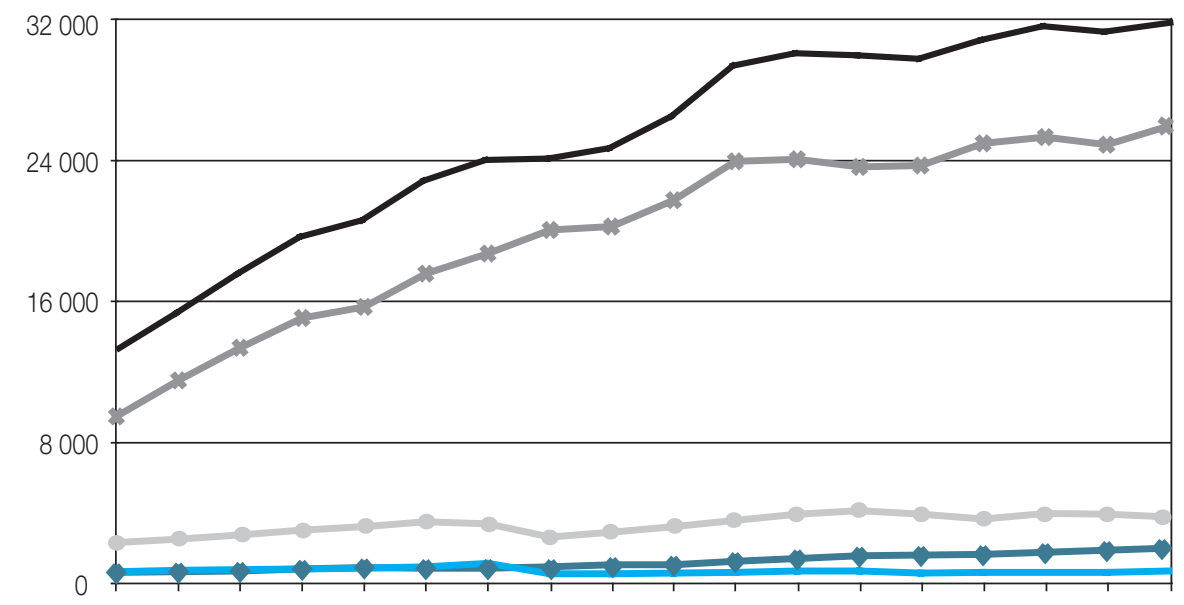

198519861987198819891990199119921993199419951996199719981999200020012002

\begin{tabular}{l}
$\begin{array}{l}- \text { China and India } \\
- \text { Middle-income countries, excl. China } \\
- \text { World }\end{array}$ \\
\hline - High-income countries
\end{tabular}

Source: See table 1. 
Figure 3. Evolution of exports (billions of current US\$)

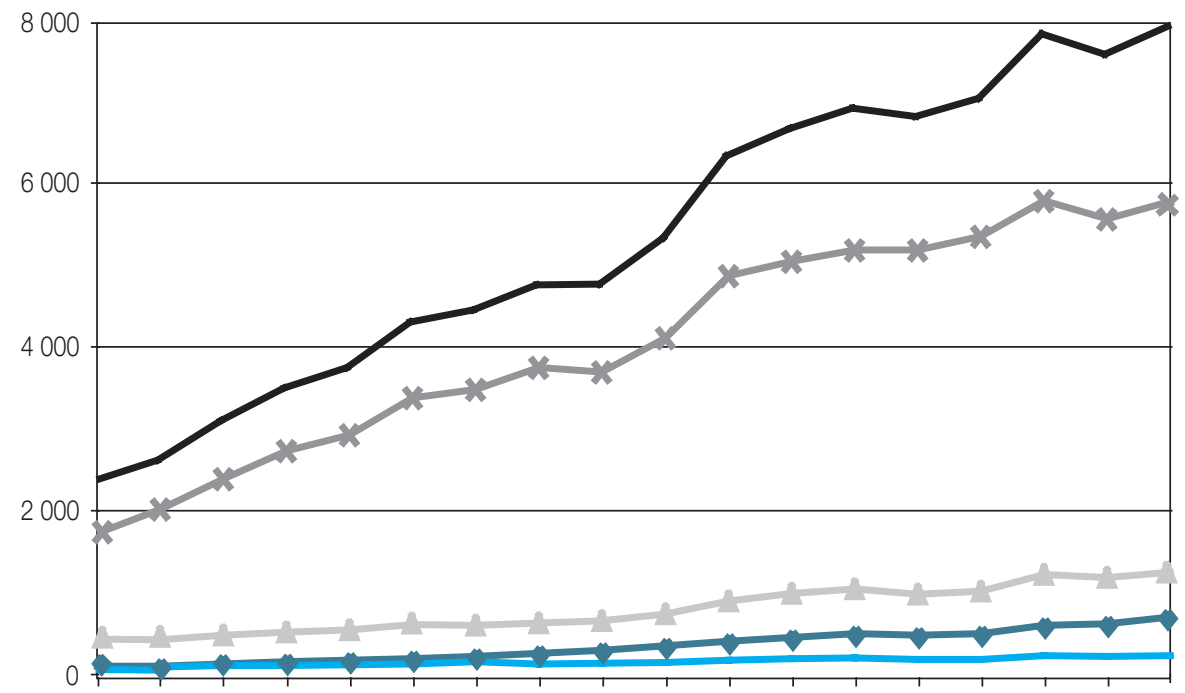

198519861987198819891990199119921993199419951996199719981999200020012002

\begin{tabular}{lll|}
- & China and India & Low-income countries, excl. India \\
- & Middle-income countries, excl. China \\
- & World
\end{tabular}

Source: See table 1.

\section{International capital}

Two main factors characterizing the globalization of international capital are now considered: foreign direct investment and portfolio investment. Foreign direct investment (FDI) is defined as investment made to acquire a lasting management interest (usually at least 10 per cent of voting stock) in an enterprise operating in a country other than that of the investor's residence. Portfolio investments are usually shorter-term capital flows, defined as the sum of portfolio investment in equity and bonds. Portfolio equity investments consist of country funds, depository receipts, and the direct purchases of shares by foreign investors.

\section{Foreign direct investment}

The data for FDI between 1985 and 2002 (table 1 and figure 4) show that, at US $\$ 633$ billion, the current world level of FDI inflows is more than ten times its 1985 level (US\$58 billion). In absolute terms, all four country-groups experienced an overall increase in the period 1985-2002. 
Figure 4. Evolution of inflows of FDI (billions of current US\$)

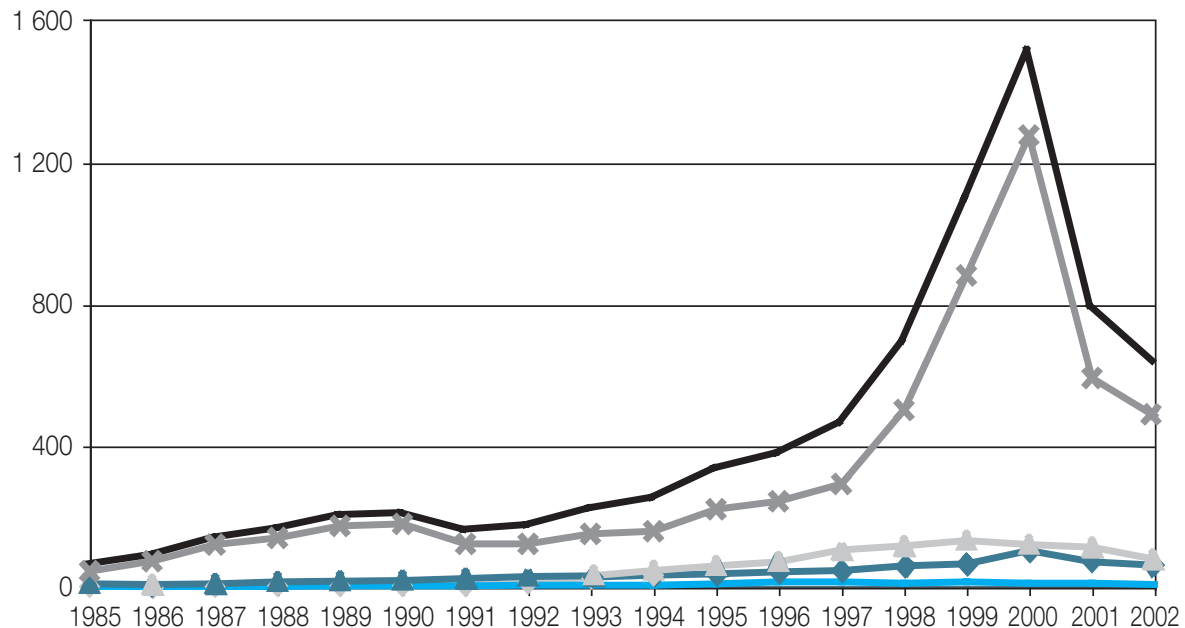

China and India
Middle-income countries, excl. China
World

However, in relative terms (defined as shares of world FDI), China and India increased their share from 2.9 per cent in 1985 to 9.8 per cent in 2002, the high-income countries experienced a marginal decrease, from 77.1 per cent in 1985 to about 76.6 per cent in 2002; in contrast the lowincome countries (excl. India) and the middle-income countries (excl. China) lost significant shares. The share of the low-income countries (excl. India) fell from an already marginal share of 3.3 per cent in 1985 to 1.1 per cent in 2002, while the middle-income countries (excl. China) decreased their share from 16.8 per cent in 1985 to 12.5 per cent in 2002. Clearly, most low- and middle-income countries did not receive the FDI inflows they were hoping for, even though they had taken measures to attract foreign capital.

\section{Portfolio investment}

The size and evolution of portfolio investment flows show an even more alarming picture (figures 5 and 6 ). First, the huge nominal differences in the levels of portfolio equity investment across income groups make it necessary to display the evolution of portfolio investment in two separate charts. Though figure 5 shows the evolution for all four country-groups, the gross inflows of portfolio investment into highincome countries are more or less identical to the world level. Figure 6 
Figure 5. Inflows of portfolio investment (billions of current US\$)

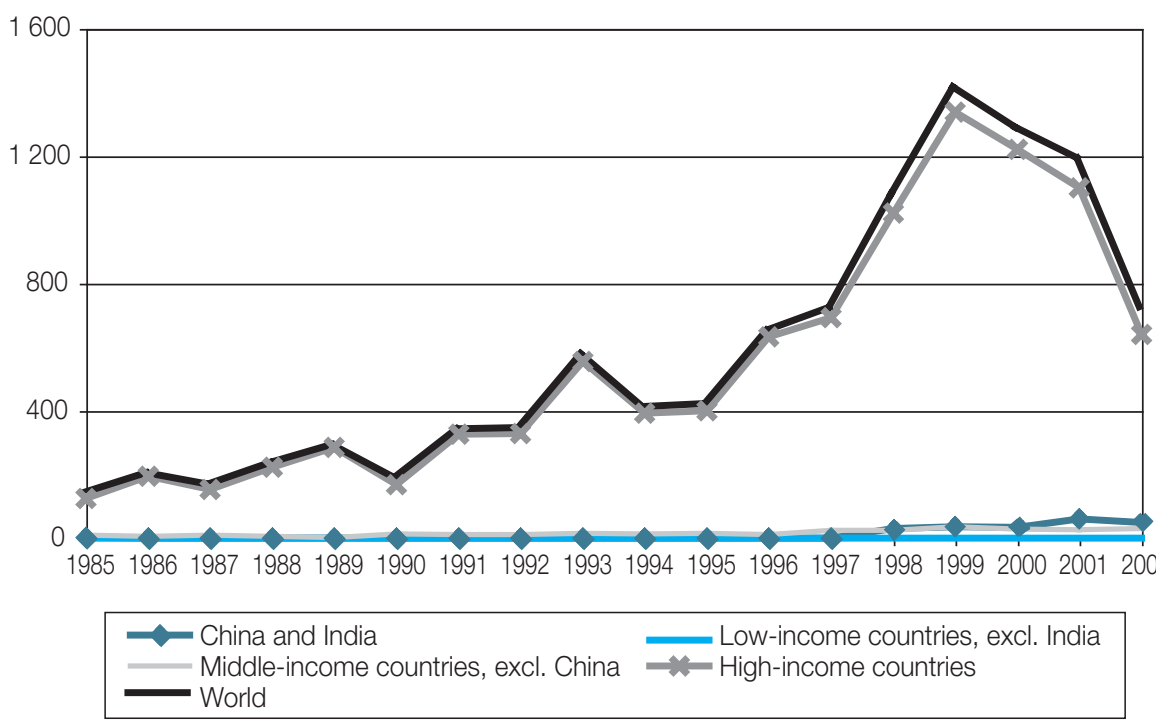

Source: See table 1.

Figure 6. Inflows of portfolio investment in low- and middle-income countries (billions of current US\$), 1985-2002

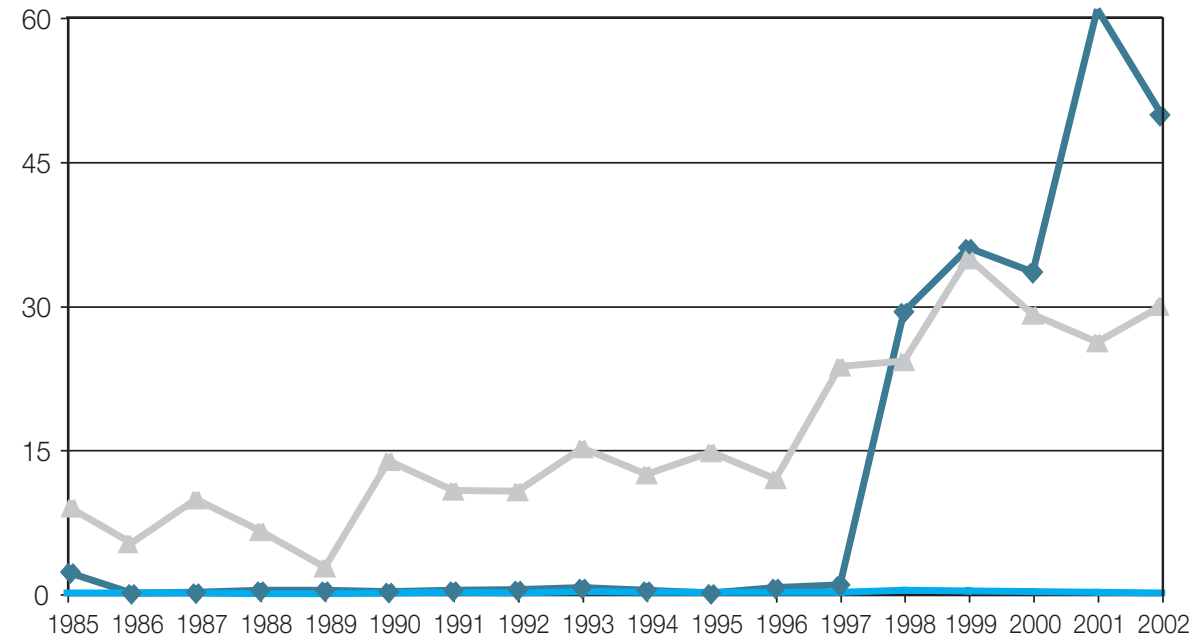

China and India
- Middle-income countries, excl. China


therefore provides details of the evolution for low- and middle-income countries.

The salient facts are that the high-income countries' share in world portfolio investment remains at around 90 per cent; that the share of the low-income countries (excl. India) decreased from around 0.04 to under 0.01 per cent; and that the share of the middle-income countries (excl. China) decreased from 6.7 to 4.2 per cent. Even India and China did not play any significant role until the late 1990s (figure 6).

\section{International production}

Recent developments in international trade and finance have been accompanied by internationalization of production (the fragmentation of production and/or intra-product specialization). This means that production is split into several separate processes which take place in different countries, hence across national borders. It can be illustrated by the modern production of cars. Though typically a car is assembled in one country, the various inputs for the final assembly (intermediate products) usually come from many different countries. The intermediate products are likely to come from plants located in other countries but owned, or at least partly owned, by the same multinational corporation (MNC) that assembles the car. Indeed, all large car corporations have set up factories for intermediate car products in the countries most profitable for the production of that specific intermediate product. In other cases, the opening of markets has led to collusive behaviour between firms and the forming of strategic crossborder alliances such as joint ventures and product-sharing schemes (see Emadi-Coffin (2002), p. 165).

Though aggregate time series data on this fragmentation are scarce, the empirical literature permits one to characterize the fragmentation aspects of globalization as follows. First, international trade increasingly appears to be in intermediate products. Second, over the past 17 years, there has been a wave of mergers and acquisitions, resulting in powerful MNCs. Today, MNCs account for over two-thirds of world trade, and their share is even greater in the trade of technologically advanced products. Third, though the developing countries' share of internationally fragmented products has remained stable over the past 17 years, the share of the low-income countries has decreased. To return to the example of modern car production, the vast majority of developing countries is not producing any car parts. As with FDI, international production within developing countries is highly concentrated in certain countries, e.g. Argentina, Brazil, China, Mexico, Singapore and Thailand. Most of the literature concludes that cross-border fragmentation of the production process has been the driving force behind the intensification of international trade. 


\section{The recent globalization process and its social dimension}

Most of the previous section was based on largely undisputed statistical data. However, a considerable part of the literature analysing the social impact of globalization is highly controversial. At the aggregate level, examining the overall social impact of globalization, most analyses fall between two polar views. For some, globalization has been an instrument for progress; it has created wealth, expanded opportunities and provided a nurturing environment for entrepreneurship and enterprise. For others, globalization has created unemployment, poverty and marginalization, and is thus perceived as a force institutionalizing social crises.

Given the volume of the literature on the impact of increased international trade on labour costs and taxes, a summary will first be made of the consensus that has emerged in that respect, concluding broadly that increased international trade has led to considerable pressure on labour costs and wages. Next follows a review of the (controversial) debate on the impact of globalization on poverty. Though the overall impact of globalization on poverty remains disputed, there is broad agreement that globalization has exacerbated inequalities because of sharply diverging experiences at the individual level. The impact of globalization on various aspects of inequality will then be reviewed. There is also some agreement among researchers that globalization has increased economic and political insecurity, even for those who have benefited from globalization. A review of the literature looking at the social impact of globalization on child labour, gender and migration concludes this section.

\section{Global pressure on wages and employment}

MNCs base their decisions on the location of production on the most competitive combination of labour, technology, structural advantages and business environment which includes, inter alia, low taxes on profit and political stability. It is well established that in the 1990s there was an intensification in competitive pressure to lower labour costs and taxes, especially in high- and middle-income countries. It is also well established that much manufacturing production moved from the industrialized countries to the developing countries, although this has not yet affected most developing countries. The shift in manufacturing production caused large-scale structural unemployment in the affected industries in most industrialized countries ${ }^{5}$ and a concurrent pressure

5 However, as Stiglitz (2003) points out for the United States, although more and more manufacturing was being moved offshore, new high-paying jobs, largely in the service sector, were created, which more than offset those lost in manufacturing (though obviously not all those previously employed in the manufacturing sector were absorbed into the service sector). 
to increase social protection, especially in state-sponsored unemployment insurance. Despite these demands, a decline in revenues resulting from lower tariffs and lower profit taxes forced many governments to cut expenditure, including in the social sector. This, some argue, led to the dismantling and rethinking of the continental European universalist social security system. As Deacon and others have pointed out, these pressures on the traditional welfare state have been perceived as a threat to equitable social welfare states. ${ }^{6}$

Considerable controversy still surrounds many aspects of the impact of globalization on wages and employment, and two recent literature reviews focus on these issues. Greenaway and Nelson (2001) reviewed many major contributions to the literature on the labour market effects of globalization, covering the relationships between: (a) trade and wages; (b) labour markets microstructure and adjustment; (c) trade and employment; (d) migration and labour market adjustment; and (e) FDI and labour markets. They covered major contributions over the past 20 years, predominantly those concerned with industrialized countries' experience. Rama (2003) reviewed the academic literature on the effects of globalization on workers in developing countries, including a description of the pattern of job destruction and job creation associated with globalization.

Most studies agree that Europe's initial resistance to cut wages and its maintenance of social protection more or less intact have led to high unemployment but no significant changes in income distribution. On the other hand, in the United States the same competitive pressure has resulted in lower industrial wages and significant changes in income distribution, even though the United States imposed some "safeguard" measures to protect the country from the negative impact of imports (Stiglitz, 2003).

At the same time, globalization led to increased competition between developing countries to set up new production plants. Nearly all developing countries have sought to get some share of increased international production by establishing export processing zones and making some concessions to MNCs, for example through tax exemptions and the public provision of infrastructure targeted to MNCs' demand. Thus, there were also large-scale structural changes in developing countries and considerable structural unemployment. Though some of these costs have been compensated at the national level in countries able to attract large-scale MNC investment (e.g. by creating new jobs, including for women and children), the traditional workforce has experienced considerable reductions in wages and jobs. Freeman (2003) finds that, overall, the debate has exaggerated the effects of trade on economies and the labour market. Changes in trade policy

6 See Benvenisti and Nolte (2004) for a recent collection of papers on these issues. 
have had a modest impact on the labour market. ${ }^{7}$ Other aspects of globalization - immigration, capital flows and technology transfer - have had greater impact, with volatile capital flows creating great risk for workers' well-being. Freeman (2003) also concludes that global labour standards do not threaten the comparative advantage of developing countries and that poor labour standards do not create a race to the bottom. Chau and Kanbur (2001) suggest that a Southern race to the bottom is possible, but not inevitable.

Ghose (2003) argues that "there is really no evidence to suggest that expanding North-South trade in manufactures has led to a competitive dilution of labour standards in either North or South" (p. 111), but points to a number of worrying developments, the foremost of which is global exclusion; a large number of developing countries, where 30 per cent of the world's population lives, have gradually become marginal to the global economy, and employment and labour standards have been declining there. Other concerns are that trade liberalization has promoted non-beneficial integration into the global economy for some (mainly Latin American) economies and that globalization has not had a stimulating effect on global economic growth.

\section{Controversy over the impact of globalization on poverty}

While the vast majority of contributions to the academic and institutional literature conclude that globalization has spurred economic growth ${ }^{8}$ and that the overall benefits of globalization are larger than its overall costs, the literature assessing the impact of globalization on poverty is considerably more controversial. The more influential (and mostly institutional) literature concludes that globalization reduced poverty. However, many individual researchers have pointed out that the empirical analysis leading to that conclusion is conceptually flawed in various ways. The comprehensive study by Oxfam International (2002), which popularized the view that current trade rules and institutions are rigged in favour of developed nations, has shown that international trade can have both a positive and a negative impact on poverty. The companion study by Oxfam America (2002), analysing the impact of private international finance on poverty, concluded that current global financial systems hurt the poor.

Examination of the impact of global finance can be broken down into studies examining the impact of FDI and of portfolio investments. Most of these assert that FDI is far more beneficial than other capital

${ }^{7}$ Blom, Goldberg, Pavcnik and Schady (2003) come to a similar conclusion.

${ }^{8}$ For a sharply differing view, see Weisbrot and Baker (2002), Weisbrot, Baker, Kraev and Chen (2001) and Weisbrot, Naiman and Kim (2000), who claim that the recent globalization process has led to diminished progress and to lower growth compared with that of the 1970s and 1980s. 
flows. Indeed, it has been asserted that the sudden increase in shortterm capital flows (largely invited by premature capital account liberalization and large-scale short-term borrowing by financially troubled governments) hold key responsibility for the various financial crises of the 1990s and that the subsequent social crises reversed much of the progress achieved previously. Hence, the International Monetary Fund (IMF), a traditional advocate of capital market liberalization, has started to suggest that "financial integration should be approached cautiously, with good institutions and macroeconomic frameworks viewed as important" (see Prasad et al. (2003), p. 5).

Agénor (2002) examined the extent to which globalization affects the poor in low- and middle-income countries, notably the possibility of a non-linear relationship. Using individual indicators of trade and financial openness, as well as a globalization index based on principal components analysis, to test for both linear and non-linear relationships between globalization and poverty, he concluded that the results suggest the existence of a non-monotonic, Laffer-type relationship between globalization and poverty. His cross-country results are consistent with the empirical data provided in the next section of this article, which show that most low-income countries have been marginalized by the globalization process of the past 15 years. Furthermore, the results are also consistent with the consensus view of the impact of globalization on inequality (see below).

\section{Globalization and inequality}

It is now widely recognized that the benefits of growth depend crucially on the distribution of the income generated by economic progress. The functional distribution of income refers to the division of national income between the factors of production, traditionally identified as labour and capital. ${ }^{9}$ The size distribution of income measures the share of income received by individuals or families within certain income-groups; this is traditionally identified as the share of total income received by different percentiles of the population. ${ }^{10}$

${ }^{9}$ It should be noted that employee ownership of stocks has increased in most industrialized countries, leading to some blurring of lines between employees and employers. Yet this increased employee stock ownership has not apparently led to more labour-friendly management decisions.

10 There are many ways of measuring inequality. For a list and description of the most commonly used measures, see: www.undp.org/poverty/initiatives/wider/wiid_measure.htm. One of the best-known measures is the Gini coefficient, which ranges theoretically from 1 (= perfect inequality) to zero (= perfect equality). In practice, Gini coefficients for the world's countries usually range between 0.25 and 0.65 . Though the relationship between GNP per capita and income distribution varies widely across countries, the data seem to indicate that, on average, income inequality tends to be higher in low-income countries. 
In the mid-1950s, Simon Kuznets, the Nobel Prize-winning economist, proposed a hypothesis that income inequality initially worsens as per capita GNP rises, peaking at intermediate income levels and declining for industrial countries. Kuznets' hypothesis is one of the bestknown and also one of the most controversial hypotheses in economic theory. Though up to the 1960s there was some empirical support for the Kuznets inverted U-curve, most re-examinations of the 1980s found little empirical evidence for such an inverse relationship. The debate continued in the 1990s, with various studies coming to different conclusions about the relevance of the Kuznets curve. In any case, there is some general agreement today that growth and equity need not be contradictory goals. Most economists also agree that there is no automatic link between economic growth and equitable human development. However, when this link is forged with policy and determination, it can reinforce the two goals and economic growth will reduce poverty and improve human development.

As regards the impact of globalization on income inequality, there is now a large literature with contributions from over 50 authors, most of whom conclude that globalization has increased income inequality within as well as between countries. Stiglitz (2003), for example, argues that, as actually practised, globalization tends to make poor societies more rather than less unequal. However, some contributors to the literature question these findings or argue that, though higher growth has been accompanied by increased inequality, poverty has still decreased.

Various early studies distinguished between the impact of economic globalization (especially trade) and the impact of technological changes, mostly concluding that the deteriorating income inequality was due to technological changes rather than globalization. However, Cornia and Court (2001) and Cornia and Kiiski (2001) showed that the widespread surges in inequality were linked to excessively liberal economic policy regimes and to the way in which economic reform policies were carried out. ${ }^{11}$

Cornia and Kiiski (2001) reviewed the changes in within-country inequality over the past 20 years on the basis of an extensive review of the literature and of an analysis of inequality trends in 73 countries accounting for over four-fifths of world population and GDP. They found that over the past 20 years inequality rose in two-thirds of these countries - a clear departure from the inequality trends recorded since the end of the Second World War. The study also suggests that, with the

11 Indeed, a recent review of the role of technological advance in changes in earnings inequality has questioned whether inequality should be viewed as a causal result of skill-biased technological change or whether there is a missing link - or perhaps no link at all - between changes in technology and changes in wage inequality. See the various contributions in Ginther and Zavodny (2002). 
exception of growing educational dispersion in Latin America, traditional causes of inequality (such as land concentration and urban bias) cannot account for the recent rise in income inequality. This appears to be related to a shift towards skill-intensive technologies and especially to the drive towards domestic deregulation and external liberalization. Of the six main components of this new paradigm, the factor most strongly contributing to rising inequality appears to have been capital account liberalization, followed by domestic financial liberalization, labour market deregulation and tax reform. Privatization was found to be associated with rising inequality in some regions but not in others, while trade liberalization had an insignificant effect on or only mildly contributed to rising inequality.

Similarly, Singh and Dhumale (2000) indicate that, with respect to developing countries, neither trade nor technology are necessarily the most important factors in increasing income inequality, though they agree that globalization (in the form of financial liberalization rather than trade) and technology are both likely to be significant factors accounting for the increased inequality in developing countries over the past 20 years. They conclude that, for developing countries, the most relevant factors are the social norms deemed acceptable, labour market institutions such as unions and minimum wages, and macroeconomic conditions.

Khan, Griffin and Riskin (1999), analysing changes in recent income distribution in urban China, conclude that increased income inequality is more likely to be due to economic reform policies (especially cuts in social protection provision) than to globalization; and that, at least in the more prosperous regions, by creating new jobs globalization has contributed to fairer income distribution. Thus, there may be some cases where the impact on income inequality can be derived from the Heckscher-Ohlin model. ${ }^{12}$ However, the overall consensus remains that globalization has led to increased income distribution both within and between countries, as long as technological changes are considered to be part of the globalization process.

Looking at the longer-term perspective, there is some agreement that income distribution deteriorated considerably during the twentieth century. According to the IMF (2000), the world Gini coefficient rose from 0.40 in 1900 to 0.48 in 2000. Bourguignon and Morrisson (2002), examining the combined effect of trends in disparities between countries and inequalities within them, conclude that international inequalities increased significantly between 1820 and 1910, remained stable from 1910 to 1960 and grew again from 1960 to 1992. Concentrating on more recent experience, Milanovic (2002) also concludes that world

12 That comparative advantage arises from the different relative factor endowments of the countries trading. 
income distribution became markedly more unequal between 1988 and 1993.

Burtless (2002) has argued that income may not be the best indicator to assess the impact of globalization on inequality and that indicators such as life expectancy would show that globalization had an equalizing impact. ${ }^{13}$ On the other hand, there is some indication that disparities in life expectancy are growing once again, because of the AIDS epidemic. Furthermore, the earlier periods of improved life expectancy may have been influenced by the spread of medical advances. Finally, life expectancy may not necessarily be a better indicator of the impact of globalization on inequality than income, especially as qualitative aspects of life are not taken into account if only life expectancy is considered.

\section{Increased global insecurity}

Insecurity can be defined in many ways. The aspects most frequently treated in the literature are job insecurity, lack of social protection, food insecurity and fear of terrorism. No matter how insecurity is defined, there is a broad consensus in the literature that globalization has increased economic, social and political insecurity, even for those who have benefited from globalization.

The most extensive coverage of issues related to job insecurity and changes in employment patterns is provided in Torres (2001a). The broader issues related to economic insecurity among workers are the subject of a recent empirical study by Scheve and Slaughter (2002)14 and various contributions in a book edited by Debrah and Smith (2002). Globalization and food security are addressed in Davis, Thomas and Amponsah (2001). The link between globalization and terrorism (among others) is made in World Bank (2002).

Although the heightened international volatility of trade, capital flows and production has contributed to increased insecurity, it is also argued that the absence of political action to counter the heightened risk and uncertainty has contributed as much, if not more, to increased global insecurity (see, especially, Nayyar (2002), Ocampo and Martín (2003) and also Cornia and Court (2001) and Deacon (2002)). Assuming that people are usually averse to risk, the more difficult question is whether the costs due to increased insecurity have been compensated

13 See Becker, Philipson and Soares (2003) for overall supporting views.

14 Scheve and Slaughter (2002) point out that the common claim that economic integration increases worker insecurity lacks empirical verification. They argue that economic insecurity among workers may be related to riskier employment and/or wage outcomes, and that foreign direct investment may be a key factor contributing to this increased risk by making labour demands more elastic. 
by the overall benefits of globalization. This is likely to be answered in the affirmative by workers and families who have been lifted out of poverty because of globalization. However, as with many other aspects of globalization, contributors to the literature seem to conclude that many poor and disadvantaged people suffer a disproportionate share of the increased insecurity, largely because of market failures that prevent them from properly balancing income and consumption.

In conclusion, globalization has increased insecurity, the growth in insecurity has aggravated the negative implications of rising inequality and - as Kaplinsky (2001) and others have argued - the combination of increased insecurity and increased inequality is so widespread that it threatens the sustainability of the current globalization process.

\section{Globalization and child labour}

The literature on the impact of globalization on child labour can be grouped in three categories. Publications in the first group alerted the public to the severe negative impact globalization has had on child labour in specific countries and specific industries. Those in the second group concentrated on the debate on the usefulness of industrialized countries' legislation, e.g. to boycott products manufactured by child workers, and the appropriateness of integrating industrialized countries' standards into international trade negotiations. Finally, those in the third group provide some empirical evidence of the impact of globalization on child labour, but take a much broader view of its impact generally. 15

The following conclusions on the social impact of globalization on child labour are based largely on publications from the third group. First, though it may initially be concluded that globalization has increased child labour activities, this was largely because of an initial shift of child labour from informal home and family enterprises into more visible, formal wage employment. Second, although clearly there were unacceptable abuses, some of this formal child labour had positive, short-term effects on the income levels of poor families. Third, because of international pressure and the fear of developing countries that industrialized countries may boycott the import of products manufactured with child labour, most developing countries have adopted restrictive child labour legislation. Some MNCs have also voluntarily eliminated child labour as a result of public pressure in industrialized countries. Though there remain severe gaps in enforcement of the legislation adopted by developing countries, recent empirical contribu-

15 As regards the latter, see especially Cornia (2002), who also examines complementary policies and programmes, such as social insurance, childcare and family support, that can best harness the benefits of globalization for children. 
tions conclude that globalization has actually reduced child labour, at least in the formal sector. ${ }^{16}$ It is not so clear how beneficial this reduction in formal child labour has been. Based on a critical review (including the results of an ILO-UNICEF study that analysed the impact of the dismissal of child workers in the Bangladeshi garment industry in 1993), White (1996) concludes that the overriding aim should be to combat the exploitation of children, rather than to exclude them from the labour market. However, this view is contested by many child labour activists and trade unions.

\section{Globalization and gender}

The literature analysing the impact of globalization on gender covers a variety of controversial issues and overall remains inconclusive. While there was an initial tendency to conclude that globalization may have reduced gender imbalances, largely owing to increases in female participation rates and associated expanding freedom resulting from women's paid work, the more recent literature tends to show that discrimination against women continues regardless. Comparing the gender literature with that on child labour, the common initial tendency is that both women and children are better integrated into formal employment. The difference is that children's increased participation rate is considered detrimental to them, whereas women's increased participation is considered beneficial for women.

There has certainly been some progress in women's social status, based on the increased female participation rate, especially in manufacturing and export processing zones. However, some of the more recent studies, especially Chambers (2000), have argued that despite the increase in female participation rates, women remain economically disempowered. Indeed, one of the reasons for the increase in female participation is that women accept lower wages. Furthermore, it has been argued that many female workers have little control over how their salary is spent and that the key responsibility for unpaid household and family work remains with women, sometimes even in households where women provide the main or only income. Some studies have also found that, in some instances, men's violence and hostility towards women has increased because of women's changed social status.

Black and Brainerd (2002) conclude that "increased competition through trade did contribute to the relative improvement in female wages in concentrated relative to competitive industries, suggesting that, at least in this sense, trade may benefit women by reducing firms' ability to discriminate" (p. i). On the other hand, Balakrishnan (2002)

16 See Cigno, Rosati and Guarcello (2002), as well as Edmonds and Pavcnik (2002). 
concludes that the international fragmentation of production has led to the flexibilization of work and that women often accept unstable and vulnerable work in order to combine their family responsibilities with paid work. Similarly, Moghadam (2001) casts a gender perspective on globalization to illustrate its contradictory effects both on women workers and on women's activism. She concludes that globalization has had dire economic effects on women; ${ }^{17}$ however, the process has created a new constituency of working and organized women, which may herald a potent anti-systemic movement.

Miller and Vivian (2002) argue that the current emphasis on trade liberalization and economic restructuring will affect many countries that have a large female workforce in labour-intensive industries; that increased competitiveness must come in large part from technological upgrading and growing labour productivity; and that the challenge is to make the transition to high-wage, high-productivity employment without substituting male workers and more socially privileged workers for the existing female workforce (drawn from lower-income households). Finally, the principal conclusions of Çağatay (2001) are: "that men and women are affected differently by trade policies and performance, owing to their different locations and command over resources within the economy; that gender-based inequalities impact differently on trade policy outcomes, depending on the type of economy and sectors, with the result that trade liberalization policies may not yield expected results; and that gender analysis is essential to the formulation of trade policies that enhance rather than hinder gender equality and human development" (p. 5).

\section{Globalization and migration}

When reviewing the impact of globalization on migration, the first observation is that the recent globalization process has been accompanied by far less international migration than at any other time in world history. There is also no doubt that the limited migration is due mostly to constraints set in industrialized countries' immigration laws. Thus, compared with earlier large-scale migrations, today's migration process is far more selective in countries of both emigration and immigration. The comprehensive analysis by Stalker (2000) concluded in this regard that some traditional migration channels, particularly those from Europe, have dried up, while many new ones are being created, notably

17 Similarly, Bielenstein (2002) concludes that globalization caused particular hardship for female workers in many Asian countries, which was aggravated by the economic crisis over recent years. 
in south-east Asia. The World Development Report 1995 has shown that today's migrants come increasingly from poor countries. ${ }^{18}$

Second, as Solimano (2001) has pointed out, today's globalization process is less friendly to the international migration of unskilled people than were previous waves of globalization. This aspect of migration (whereby the best educated emigrate) has long been known and is commonly referred to as the "brain drain". There is broad agreement that emigration has a very negative impact on labour supply in some developing countries, especially as most of the emigrants belong to the most productive and best-educated section of the labour force. For example, Adams (2003) concludes that a large proportion of the best educated emigrate from the five Latin American countries located close to the United States (Dominican Republic, El Salvador, Guatemala, Jamaica and Mexico).

On the other hand, sending countries benefit from migration because of the remittances migrants send back to their country of origin. The World Bank's publication Global Development Finance 2003 has a good section on remittances, showing that for the top 20 developing-country recipients of development finance, in 2001 the share of workers' remittances in GDP varied from 7 per cent (Sri Lanka) to 37.4 per cent (Tonga) (World Bank, 2003a). ${ }^{19}$ Though these remittances improve the living standards of the receiving families, they contribute little to the sending countries' development and, thus, the emigration of the best-educated and most productive workers remains a problem, especially in the poorest countries.

A variety of issues relating to the migration of people in a global economy are also addressed in three contributions to Baker, Epstein and Pollin (1999). ${ }^{20}$ Nayyar (2002) tentatively concludes that the time has come to initiate moves towards a new institutional framework to govern cross-border movements of people. This will be returned to in greater detail in the next section.

18 Data from Pakistan indicate that about 25 per cent of the incremental labour supply left the country in the period 1978-83 (World Bank, 1995).

19 Using a new database on international remittances, Adams and Page (2003) suggest that international remittances have a strong impact on poverty reduction. On average, a 10 per cent increase in the share of international remittances in a country's GDP will lead to a 1.6 per cent decline in the share of people living in poverty.

20 To quote the introduction by the three editors, "Sutcliffe's paper frames the issue boldly with his argument that, as a matter of principle, international borders should be open" (p. 29). While recognizing that this is a utopian prospect in the current environment, Sutcliffe argues that a clear policy approach flows from his principled position: first, that borders should be open to the maximum extent; and second, that the rights of immigrants in host countries should be broadened. He further argues that the absence of principled perspectives in western Europe has been a major factor poisoning attitudes toward migrants there. DeFreitas' contribution focuses on the practical constraints on immigration in the United States and, in particular, the impact of increased migration on US labour markets and the public sector. The third paper by Patnaik and Chandrasekhar focuses on the effects of emigration of less-skilled workers in developing economies which, according to the authors, produces unequivocally beneficial effects for the sending country. 


\section{National and international policy responses}

There is no dearth of suggestions for policy responses in the recent literature. These range from calls for protectionist policy measures to changes in national education plans and also include the creation of new international organizations. First comes a short overview of the broad policy suggestions, emphasizing the role of the State and the complementarities between actors and policies; then views expressed in the literature concerning selected national and key international policies are discussed in greater detail.

\section{Overview of policy responses}

The literature on comprehensive policy responses to globalization (by contrast with single responses, such as protectionism) is relatively new and came in the wake of the vast literature on structural adjustment programmes, which examined how issues such as trade liberalization and debt relief, and national economic reform issues such as market liberalization and privatization have affected growth and poverty. After the outbreak of the Asian crisis in 1997, public and academic opinion became more concerned with policy action to prevent or reduce the negative effects of globalization (Lee, 1998). In addition, it has been suggested that the returns from globalization and their distribution can be improved through an appropriate policy mix. This is comprehensively outlined in ECLAC (2002), Khor (2001), Ocampo and Martín (2003), Torres (2001a) and World Bank (2002). UNCTAD (1996) also provided ten broad recommendations, based on 14 interagency contributions, analysing the effects of globalization (especially liberalization) on poverty.

Torres (2001a) provides a synthesis of seven country-specific studies of the social impact of globalization (Bangladesh, Chile, the Republic of Korea, Mauritius, Poland, South Africa and Switzerland). ${ }^{21} \mathrm{He}$ then suggests a variety of policies to enhance business opportunities arising from globalization and to strengthen the four social pillars (education and training, social safety nets, labour law and core labour standards) which, apart from being important in themselves, can help enhance the gains from globalization.

Khor (2001) identifies a variety of lessons to be learned from the experience of liberalization. His more general proposals include the

21 The seven studies were assembled in response to a mandate by the ILO's Working Party on the Social Dimensions of the Liberalization of International Trade. See Paratian and Torres (2001) for the Bangladesh study; Reinecke and Torres (2001) for the Chile study; Torres (2001b) for the Republic of Korea study; Anker, Paratian and Torres (2001) for the Mauritius study; Torres et al. (2001) for the Poland study; Hayter, Reinecke and Torres (2001) for the South Africa study; and Romero and Torres (2001) for the study on Switzerland. 
balancing of opportunities and problems arising from globalization, the need for South-South policy coordination between developing countries, the need for appropriate and democratic global governance, a rebalancing of the roles of State and market, and a search for appropriate development strategies.

Though it repeatedly stressed that globalization has been a force for poverty reduction, the World Bank's policy research report, Globalization, growth, and poverty emphasized seven policy programmes which the authors saw as particularly important to make globalization work for the poor: (a) a "development round" of trade negotiations; (b) improving the investment climate in developing countries; (c) good delivery of education and health services; (d) the provision of social protection tailored to the more dynamic labour market in an open economy; (e) a greater volume of better-managed foreign aid; (f) additional debt relief; and $(\mathrm{g})$ the tackling of greenhouse gases and global warming (World Bank, 2002).

Both Ocampo and Martín (2003) and the ECLAC (2002) report extensively describe forms of policy action covering four fundamental principles for the construction of a better global order; five national strategies for dealing with globalization; the key role of action at the regional level; and six, more specific global agendas. The four fundamental principles address three key objectives: ${ }^{22}$ global rules and institutions that respect diversity; the complementarity of global, regional and national institution-building; and equitable participation and appropriate governance. The five national strategies suggested for dealing with globalization concern (a) the role and basic composition of national strategies; (b) macroeconomic strategy; (c) the building of systemic competitiveness; (d) aspects of environmental sustainability; and (e) various social strategies. The global agendas address (a) global macroeconomic public goods; (b) sustainable development as a global public good; (c) the correction of financial and macroeconomic asymmetries; (d) the overcoming of production and technological asymmetries; (e) the full inclusion of migration on the international agenda; and (f) the establishment of economic, social and cultural rights as the foundations of global citizenship.

Though the Asian crisis spawned a wide range of publications, several key ones produced prior to that crisis called the (then) largely unchallenged globalization process into question: Boyer and Drache (1996), Deacon, Hulse and Stubbs (1997), Geider (1997), Gill (1997), Hart and Prakash (1997a, 1997b), Mittelman (1996), Rodrik (1997), Siebert (1997) and UNCTAD (1996). Though many, more critical contributions have been published since 1997, it is fair to say that few of the

22 The supply of global public goods, the correction of international asymmetries, and the establishment of a rights-based global social agenda. 
policies they suggested have been implemented. In addition to the contributions already mentioned, and excluding the specific recommendations made in the wide literature on labour issues, ${ }^{23}$ comprehensive policy action has recently also been suggested by Eichengreen (2002), Masson (2001) and Murshed (2002). Juxtaposing the pre- and postAsian crisis literature, one general conclusion is that more action is needed to avoid further social unrest since this, as Bourguignon et al. (2002) have pointed out, could destroy many of the real gains achieved through globalization.

\section{The role of the State and complementarities}

There is some agreement on the view that globalization has reduced the autonomy of the nation-State in economic matters, but there is also agreement that globalization calls for increased state "activity" in social matters; see, for example, the extensive discussion in Chang (2003), Nayyar (2001) and Woolcock (2001). In other words, the reduced role of the State in economic matters needs to be complemented by an increased role of the State in social matters. Some argue that a redefined role of the State in economic issues is also needed to counteract asymmetrical markets and information deficiencies (see Stiglitz (2002)), in order, for example, to address recent corporate scandals and to counter underinvestment in human capital. However, there is controversy over what exactly the State should or should not do, which instruments to use and how to finance policy measures (whether through user fees or taxes, for example).

Furthermore, while globalization requires some homogenization of policies, there are many areas in which differences in national standards need to be respected and the imposition of international standards could do more harm than good in trying to make globalization more inclusive and effective. Murshed (2000) provides a useful discussion of this issue in relation to environmental and labour standards. ${ }^{24}$

The principle of subsidiarity is key in decisions about who should act regarding the design, advocacy and implementation of policies on the social dimension of globalization. According to this principle, many different actors may be involved: individuals, families, businesses, trade unions, governments and all kinds of organizations (including nongovernmental organizations (NGOs), regional development institutions and global institutions). The recent ECLAC report, Globalization and

23 As regards the numerous policy proposals made in the huge literature on labour issues, see Greenaway and Nelson (2001), Lee (2000), Memedovic, Kuyvenhoeven and Molle (1998), Rama (2003), Stiglitz (2002) and van der Hoeven and Taylor (2000). Rama (2003) cautions: "the most effective ways to mitigate the adverse effects of globalization are probably out of the labor market" (p. 22). For proposals on gender and labour markets, see Tzannatos (1999).

24 The importance of core labour standards is addressed in greater detail below. 
development, provides a detailed discussion of the complementarity of global, regional and national institution-building (ECLAC, 2002). In many cases, there will be some complementarity between the various actors who, if properly coordinated, could reinforce individual actions. Finally, most of the recent national and international policy proposals to achieve growth and reduce poverty imply policy measures that will make globalization a more equitable and sustainable process. ${ }^{25}$

The national and international policies considered below are a selection of policies closely related to globalization and do not constitute an exhaustive list.

\section{Selected national policy responses}

Given that countries are at different stages of development and have different institutions and priorities, national policy responses will vary from country to country. However, some national policy actions are common to all governments and have received attention in the recent globalization literature: (a) investment in education and training; (b) adoption of core labour standards; (c) the provision and improvement of social protection; (d) the tackling of rising national inequality; and (e) facilities to discuss globalization. Many other policies are gaining importance in an increasingly globalized world: sustainable macroeconomic policies; policies promoting a sound investment climate; prudent financial regulations; and a variety of sector-specific policies. ECLAC (2002) provides an overview of these more "traditional" policies.

\section{Investment in education and training}

There is broad agreement that the most rewarding policy action is investment in education and training, including upgrading policies and institutions that manage innovation. The poorest countries are advised to concentrate initially on the provision of free basic education (complemented by free basic health services, such as immunization); middleand high-income countries may need to adjust their education curriculum. Given that in several cases globalization has led not only to frictional but also to considerable structural unemployment, it is also important to provide targeted training to the unemployed, which would allow them to switch to occupations in greater demand. Recent experience shows that the goal of universal primary education may require families from the poorest segments of society to be compensated for income lost as a result of sending their children to school. The impor-

\footnotetext{
25 See, for example, Cornia (2004) and Shorrocks and van der Hoeven (2004).
} 
tance of education and training and related issues are described and discussed in greater detail in ECLAC (2002, pp. 108-109), Eichengreen (2002, pp. 22-29), Torres (2001a, pp. 54-56), UNCTAD (1996, pp. 1819), World Bank (2002, pp. 156-157) and various contributions to Henry et al. (2001).

\section{Adoption of core labour standards}

There is now also broad agreement that adopting the four core labour standards (elimination of child labour, abolition of forced labour, encouragement of non-discrimination in employment, and freedom of association and collective bargaining) is highly effective in making globalization more equitable. However, differences in national definitions (e.g. what actually constitutes child labour) clearly need to be respected. In most cases, the adoption of each core labour standard calls for complementary policy action, such as compensation for family income lost as a result of eliminating child labour (mentioned above). Issues concerning core labour standards are described in greater detail in Torres (2001a, pp. 63-66), as well as in many other contributions going back at least to the mid-1990s; see Freeman (1998), Maskus (1997), OECD (1995 and 1996), Rodrik (1996) and Srinivasan (1994).

\section{Provision and improvement of social protection}

There is some agreement in the literature that more effective social protection systems are needed, in view of the negative social impact of certain policies currently being carried out under globalization. The problem is that there are widely different views of what constitutes effective social protection and how to finance it. Various authors argue that globalization (among many other factors) has contributed to the dismantling of certain aspects of social protection and social insurance, notably social protection models based on universal coverage and large government expenditure in the industrialized countries. Though some call for the classical model to be fully restored, others prefer new models based on privatizing contributions and management. The most comprehensive recent studies reviewing globalization and social policy are Deacon (2000, 2001 and 2002), Gough (2001), Norton (2000), Norton and Conlin (2000) and Yeates (2001 and 2002). As regards effective unemployment insurance, it has been suggested that one very successful complementary policy is delivery of active labour market programmes.

\section{Addressing the growth of national income inequality}

Whereas the three previously mentioned policies are likely to contribute to making globalization more equitable, pressure is building to address increasing national income inequality directly through policy measures. One of the strongest arguments for such direct action is 
based on recent research results which concluded that the elasticity of poverty rate in relation to economic growth ${ }^{26}$ is higher in more egalitarian societies. Cornia and Court (2001) provide a more detailed discussion of policies that might serve to reduce inequality, notably the promotion of employment-intensive growth. Various complementary labour market policies (e.g. measures that increase labour market flexibility) can be very effective in reducing inequality (van der Hoeven (2000)).

\section{Facilities for discussing globalization}

Finally, a relatively simple, and costless, policy would be to enable the discussion of globalization. In developing countries, this could be done as part of the consultation process already under way for the formulation of Poverty Reduction Strategy Papers (PRSPs). In most other countries, such discussion could easily be provided through the grassroots networks developed by most political parties, and thence fed back into the political decision-making process. One of the goals of the WCSDG is to make such a consultation process a cornerstone of national and international policies on globalization. ${ }^{27}$

\section{International policy responses}

Many international policy responses have been proposed, some of them dating back before the discussion on the current wave of globalization. Examples are the reform of the international financial institutions (IFIs) and the United Nations, increased development aid, debt relief, international taxes and tax coordination. However, only two sets of policy action have received broad support in the literature: a development round of trade negotiations; and a new financial architecture. Various forms of political opposition must be overcome before they can be implemented.

\section{A development round of trade negotiations}

As a reaction to the increasingly unfair rules applying to international trade, there have been widespread calls for a development round of trade negotiations. Probably the best-known trade-related issues are industrialized countries' trade restrictions on developing countries'

26 The elasticity of poverty rate in relation to economic growth (also called the poverty elasticity of growth) is a measure of how much economic growth contributes to the reduction of poverty. For further details, see Heltberg (2002).

27 For the most recent consultation processes initiated or in progress, see the World Commission's website: www.ilo.org/public/english/wcsdg/index.htm. 
agricultural goods, combined with industrialized countries' subsidies for their domestically produced agricultural products; and the question of intellectual property rights on urgently needed medication to fight AIDS. At a broader level, Rodrik (2001) has suggested that the focus needs to shift from promoting liberalization to fostering development. As the current setback in the World Trade Organization's (WTO) negotiations shows, many developing countries are not convinced that further extensions of the WTO's authority - into areas going far beyond traditional trade - will be beneficial to them. In addition to various ways of improving the developing countries' negotiating capabilities, it has been suggested that the WTO's single undertaking mandate and its consensus-building process be revised. There has therefore been an increase in bilateral trade agreements, even though these represent a second-best solution, especially if they are forced on to developing countries with the promise of other benefits.

\section{A new financial architecture}

In view of the increasing volatility of world financial markets, which render them prone to financial crises, there have been widespread calls for the construction of a new financial architecture. The Financial Stability Forum (consisting of high-ranking representatives of G-7 countries and major IFIs) was established in 1999, with the explicit mandate of identifying gaps and weaknesses in the international financial system. Yet the content of reform packages for a new financial architecture has thus far been limited to a few, highly contentious individual policies, such as the introduction of standards and codes; various proposals for a new workout mechanism for international debt; ${ }^{28}$ and various suggestions for the introduction of capital controls and/or currency transaction taxes (such as the Tobin tax).

Besides publishing its Global Financial Stability Report twice a year, the International Monetary Fund (IMF) has mostly adopted a bilateral approach to its member countries, concentrating on identifying country-specific vulnerabilities and shock absorbers. Akyüz (2002) provides a comprehensive discussion of ways of reforming the global financial architecture, suggesting various improvements to the governance of international capital flows and the exchange rate system, an orderly workout mechanism for international debt, and a fundamental reform of the operation and governance of the IMF and other IFIs.

28 The huge differences between proposals for such an international debt workout mechanism are illustrated by the IMF's Sovereign Debt Restructuring Mechanism (SDRM), contrasted with the Fair and Transparent Arbitration Procedure (FTAP) called for by international advocacy groups. 


\section{Second-generation proposals}

In addition to numerous suggestions on the specific roles of the United Nations system, the ILO, the IMF and the World Bank, ${ }^{29}$ there are various so-called "second-generation" proposals which were made before the discussion on globalization gained momentum. Many of these proposals have attracted renewed attention in the recent literature, but they have lacked sufficient political support, at least until now. These include various proposals concerning: reform of existing international institutions, among which calls for changes in the governance structure of the World Bank and IMF are currently popular; 30 the creation of new international organizations; the integration of social goals into international agreements; the tackling of global inequality through international taxation; and various issues related to international migration. The most detailed elaboration of these second-generation proposals is provided by Nayyar (2002). There have also been many (mostly unsuccessful) attempts to make global policy less neo-liberal and somewhat more socially responsible. In this connection, Deacon (2003) has suggested that it might be useful to shift the focus for improving the world's management of global social issues toward networks, partnerships and projects.

\section{Policies requiring international agreement}

Finally, many proposals for policy action can only be addressed effectively through international agreements. Some of these reform proposals are not directly related to the recent globalization process, for example, the provision of more and better-managed foreign aid; more debt relief for the poorest and most indebted countries; and suggestions regarding environmental issues, such as greenhouse gases and global warming. If there are gaps in the global governance system preventing these issues from being addressed effectively, new international organizations may be needed. Recent collections of papers addressing such global governance issues can be found in Siebert (2003), as well as in McCann and McCloskey (2003).

\section{Conclusions}

Over the past 15 years, the key economic aspects of the globalization process have been: 2003).

${ }^{29}$ For example, see Gudgeon (2001), Hagen (2003), Köhler (2003) and Wolfensohn (2001,

30 See Buira (2002, 2003) and Jacobs (2002). 
- a more than threefold increase in international trade, although the low-income countries' share in world trade has decreased considerably;

- a more than 20-fold increase in FDI across the world, although the low-income countries' share in world FDI has decreased drastically;

- a more than 20-fold increase in portfolio equity investment across the world, although the low-income countries' share (excl. India) remains close to zero; and

- the increased fragmentation of production, accompanied by a decline in the share of developing countries in international production.

The enormous range of contributions to the literature on globalization shows clearly the continuing controversy over the social impact of globalization on poverty, child labour, gender and migration. However, a consensus does seem to be emerging that, overall, globalization has brought more benefits than costs; that it has exacerbated inequalities both within and between countries because of the sharply diverging experience at individual and country levels; and that it has increased economic and political insecurity even for those who have benefited in monetary terms from globalization. Yet it is still a challenge to make causal links between changes in poverty and inequality with increased economic globalization, as the globalization process today has an impact far beyond its economic aspects, and is increasingly influenced by global health and environmental crises (such as the AIDS epidemic and climate change). Certainly, even if globalization is not the major cause of income inequality and poverty, it is likely to have contributed to the poor performance of efforts to reduce poverty (Kohl, 2003).

As Stiglitz (2003) has expressed it, although globalization did not often produce the promised benefits, the issue is not whether globalization can be a force for good which benefits the poor of the world (which it of course can be), but that globalization needs to be managed in the right way - and too often this has not been the case. As documented in this article, most of the details regarding the size, implementation and financing of national and international policy to manage the process of globalization remain controversial. However, there seems an emerging consensus that governments need to invest in education and training, adopt core labour standards, provide and improve social protection, tackle rising national inequality and provide space and opportunity to discuss globalization. At the international level, two sets of policy action have received broad support in the globalization literature: a development round of trade negotiations; and a new financial architecture. Much more discussion and research will be required at national and international levels to make globalization a more sustainable proc- 
ess in social terms. Too many people still live in conditions that are unacceptable in the twenty-first century. A start has been made and, with the cooperation of the wide range of agents active in an increasingly globalized world ${ }^{31}$ and of those so far marginalized or excluded, there is some hope for the future. For, as Storm and Naastepad (2001) put it, development will not happen by globalization alone.

\section{References}

Adams, Richard H. Jr. 2003. International migration, remittances, and the brain drain: A study of 24 labor-exporting countries. Policy Research Working Paper No. 3069 (May). Washington, DC, World Bank. Downloadable on: http://rosalinda.ingentaselect.com/ wb/wpaperspdf/3069.pdf [visited 22 Apr. 2004].

-; Page, John. 2003. International migration, remittances, and poverty in developing countries. Policy Research Working Paper No. 3179 (Dec.). Washington, DC, World Bank. Downloadable on: http://econ.worldbank.org/files/31999_ups3179.pdf [visited 22 Apr. 2004].

Agénor, Pierre-Richard. 2002. Does globalization hurt the poor? Policy Research Working Paper No. 2922 (Oct.). Washington, DC, World Bank. Downloadable on: http:// rosalinda.ingentaselect.com/wb/wpaperspdf/2922.pdf [visited 22 Apr. 2004].

Akyüz, Yilmaz (ed.). 2002. Reforming the global financial architecture: Issues and proposals. Geneva, UNCTAD/Penang, Third World Network/London, Zed Books.

Anker, Richard; Paratian, Rajendra; Torres, Raymond. 2001. Mauritius. Studies on the Social Dimension of Globalization. Geneva, ILO.

Baker, Dean; Epstein, Gerald; Pollin, Robert (eds.). 1999. Globalization and progressive economic policy. Cambridge, Cambridge University Press.

Balakrishnan, Radhika (ed.). 2002. The hidden assembly line: Gender dynamics of subcontracted work in a global economy. Bloomfield, CT, Kumarian Press.

Becker, Gary S.; Philipson, Tomas J.; Soares, Rodrigo R. 2003. The quantity and quality of life and the evolution of world inequality. NBER Working Paper No. 9765 (June). Cambridge, MA, National Bureau of Economic Research. Downloadable on: www.nber.org/papers/w9765.pdf [visited 22 Apr. 2004].

Benvenisti, Eyal; Nolte, Georg (eds.). 2004. The welfare state, globalization, and international law. Berlin and New York, Springer.

Bielenstein, Dieter. 2002. The social dimension of globalization: A critical assessment by civil society. Conference Report of an Asian Regional Conference held at Thammasut University, Bangkok, 17-18 Dec. 2002. Berlin, Friedrich Ebert Stiftung, Dialogue on Globalization. Downloadable on: http://fes.globalization.think-visually.de/pubDriver/ clients/fesDog/attachments/020101_01_Bang.pdf [visited 5 May 2004].

Birdsall, Nancy; Hamoudi, Amar. 2002. Commodity dependence, trade, and growth: when "openness" is not enough. Working Paper, No. 7 (May). Washington, DC, Center for Global Development. Downloadable on: www.cgdev.org/docs/cgd_wp007.pdf [visited 22 Apr. 2004].

Black, Sandra E.; Brainerd, Elizabeth. 2002. Importing equality? The impact of globalization on gender discrimination. NBER Working Paper No. 9110 (Aug.). Cambridge, MA, National Bureau of Economic Research. Downloadable on: www.nber.org/papers/ w9110.pdf [visited 22 Apr. 2004].

31 For example, building on the work of the World Commission on the Social Dimension of Globalization, labour ministers of the Group of Eight (G-8) called for the creation of a forum for dialogue on social issues which would include the ILO, UNCTAD, the WTO, the World Bank and the IMF (Tribune de Genève, 17 Dec. 2003). 
Blom, Andreas; Goldberg, Pinelopi; Pavcnik, Nina; Schady, Norbert. 2003. Trade liberalization and labor market adjustment in Brazil. Policy Research Working Paper No. 2982 (Feb.). Washington, DC, World Bank. Downloadable on: http://econ.worldbank.org/ files/24465_wps2982.pdf [visited 22 Apr. 2004].

Bourguignon, Francois; Morrisson, Christian. 2002. "Inequality among world citizens: 18201992", in American Economic Review (Nashville, TN) Vol. 92, No. 4 (Sep.), pp. 727744.

-; Coyle, Diane; Fernández, Raquel; Giavazzi, Francesco; Marin, Dalia; O’Rowles, Kevin H.; Portes, Richard; Seabright, Paul; Venables, Anthony; Verdier, Thierry; Winters, L. Alan. 2002. Making sense of globalization: A guide to the economic issues. CEPR Policy Paper No. 8 (July). Washington, DC, Center for Economic Policy Research.

Boyer, Robert; Drache, Daniel (eds.). 1996. States against markets: The limits of globalization. London, Routledge.

Buira, Ariel. 2003. "The governance of the IMF in a global economy" in Ariel Buira (ed.): Challenges to the World Bank and IMF: Developing country perspectives. London and Nashville, TN, Anthem Press, pp. 13-36.

-. 2002. "Reforming the governance of the Bretton Woods institutions", in OPEC Fund: Financing for development. Vienna, OPEC Fund for International Development, pp. 213-255.

Burtless, Gary. 2002. Is the global gap between rich and poor getting wider? Mimeo. Washington, DC, Brookings Institution.

Çağatay, Nilüfer. 2001. Trade, gender and poverty. Background paper to the UNDP project on Trade and Sustainable Development (Oct.). New York, NY, UNDP. Downloadable on: www.undp.org/mainundp/propoor/docs/pov_tradegenderpoverty_doc.pdf [visited 5 May 2004].

Chambers, Julia. 2000. Gender and globalisation: Trade liberalisation and gender equality. Background paper for the Department for International Development's White Paper Eliminating world poverty: Making globalisation work for the poor. Downloadable on: www.dfid.gov.uk/Pubs/files/whitepaper2000.pdf [visited 7 May 2004].

Chang, Ha-Joon. 2003. Globalisation, economic development and the role of the state. Penang, Third World Network/London, Zed Books.

Chau, Nancy H.; Kanbur, Ravi. 2001. The race to the bottom, from the bottom. CEPR Discussion Paper No. 2687 (Feb.). London, Centre for Economic Policy Research.

Cigno, Alessandro; Rosati, Furio C.; Guarcello, Lorenzo. 2002. "Does globalization increase child labor?", in World Development (Oxford), Vol. 30, No. 9 (Sep.), pp. 1579-89.

Cornia, Giovanni Andrea (ed.). 2004. Inequality, growth and poverty in an era of liberalization and globalization. Oxford, Oxford University Press.

- (ed.). 2002. Harnessing globalisation for children. New York, NY, United Nations Children's Fund (UNICEF). Downloadable on: www.unicef-icdc.org/research/ESP/globalization/globalization_index.html [visited 5 May 2004].

-; Court, Julius. 2001. Inequality, growth and poverty in the era of liberalization and globalization. WIDER Policy Brief No. 4. Helsinki, United Nations University/World Institute for Development Economics Research. Downloadable at: www.wider.unu.edu/ publications/publications.htm [visited 5 May 2004].

-; Kiiski, Sampsa. 2001. Trends in income distribution in the post-World War II period: Evidence and interpretation. WIDER Discussion Paper No. 2001/89 (Sep.). Helsinki, United Nations University/World Institute for Development Economics Research. Downloadable on: www.wider.unu.edu/publications/publications.htm [visited 5 May 2004].

Davis, Carlton G.; Thomas, Clive Y.; Amponsah, William A. 2001. "Globalization and poverty: Lessons from the theory and practice of food security", in American Journal of Agricultural Economics (Malden, MA), Vol. 83, No. 3 (Aug.), pp. 714-721.

Deacon, Bob. 2003. Global social governance reform. GASPP Policy Brief No. 1 (Jan.). Sheffield, Globalism and Social Policy Programme (GASPP)/University of Sheffield, Department of Sociological Studies. Downloadable on: www.gaspp.org/publications/ brief1_summary.htm [visited 5 May 2004]. 
-. 2002. "Globalization and the challenge for social security", in Roland Sigg and Christina Behrendt (eds.): Social security in the global village. New Brunswick, Transaction Publishers, pp. 17-30.

-. 2001. "International organisations, the European Union and global social policy", in Robert Sykes, Bruno Palier, and Pauline M. Prior (eds.): Globalization and the European welfare states: Challenges and change. Houndmills, Basingstoke (Hants), Macmillan.

-.2000. "Globalisation: A threat to equitable social provision?", in IDS Bulletin (Brighton), Vol. 31, No. 4 (Oct.), pp. 32-41; also published as: Globalization and social policy: The threat to equitable welfare. Occasional Papers. Geneva, UNRISD.

-; Hulse, Michelle; Stubbs, Paul. 1997. Global social policy: International organizations and the future of welfare. London, Sage Publications.

Debrah, Yaw A.; Smith, Ian G. (eds.). 2002. Globalization, employment and the workplace: Diverse impacts. London and New York, NY, Routledge.

Dølvik, Jon Erik; Tørres, Liv. 2002. Globalisation, work, and labour standards. The Globalisation Project 2001-2002, Report No. 9 (Apr.). Oslo, Norwegian Ministry of Foreign Affairs. Downloadable on: http://odin.dep.no/archive/udvedlegg/01/03/rapp9064.pdf [visited 5 May 2004].

Economic Commission for Latin America and the Caribbean (ECLAC). 2002. Globalization and development. Santiago de Chile, ECLAC. UN No. LC/G.2157 (SES.29/3), 15 Apr. 2002.

Edmonds, Eric; Pavcnik, Nina. 2002. Does globalization increase child labor? Evidence from Vietnam. NBER Working Paper Series No. 8760 (Feb.). Cambridge, MA, National Bureau of Economic Research. Downloadable on: http://papers.nber.org/papers/ w8760.pdf [visited 27 Apr. 2004].

Eichengreen, Barry. 2002. "Capitalizing on globalization", in Asian Development Review (Manila), Vol. 19, No. 1, pp. 14-66. Downloadable on: www.adb.org/documents/periodicals/adr/ADR_Vol19_1.pdf [visited 27 Apr. 2004].

Emadi-Coffin, Barbara. 2002. Rethinking international organization: Deregulation and global governance. London, Routledge.

Freeman, Richard, B. 2003. Trade wars: The exaggerated impact of trade in economic debate. NBER Working Paper No. 10000 (Sep.). Cambridge, MA, National Bureau of Economic Research. Downloadable on: www.nber.org/papers/w10000.pdf [visited 27 Apr. 2004].

-.1998. "What role for labor standards in the global economy?" Draft for discussion. Cambridge, MA, Harvard University. Downloadable on: www.nber.org/ freeman/Papers \%20on\%20RBF\%20website/un-stan.pdf [visited 5 May 2004].

Geider, William. 1997. One world, ready or not: The manic logic of global capitalism. New York, NY, Allen Lane.

Ghose, Ajit Kumar. 2003. Jobs and incomes in a globalizing world. Geneva, ILO.

Gill, Stephen (ed.). 1997. Globalization, democratization, and multilateralism. New York, NY, St. Martin's Press.

Ginther, Donna K.; Zavodny, Madeline (eds.). 2002. Technology, growth and the labor market. Dordrecht, Boston, and London, Kluwer Academic Publishers.

Gough, Ian. 2001. "Globalization and regional welfare regimes: The East Asian case", in Global Social Policy (London), Vol. 1, No. 2 (Aug.), pp. 163-189.

Greenaway, David; Nelson, Douglas R. 2001. Globalisation and labour markets: Literature review and synthesis. Research Paper No. 2001/29. Nottingham, Leverhulme Centre for Research on Globalisation and Economic Policy, University of Nottingham.

Gudgeon, Peter S. 2001. Globalization and rural poverty reduction: The role of the United Nations system - contrasting styles and competing models. Paper prepared for the United Nations Expert Group Meeting on "Globalization and Poverty Reduction: Can the Rural Poor Benefit from Globalization?", held in New York, 8-9 Nov. 2001. Downloadable on: www.un.org/esa/socdev/poverty/poverty_egm.htm [visited 27 Apr. 2004]. 
Gunter, Bernhard G. 2004. A comprehensive collection of the recent literature on the social impact of globalization. Geneva, ILO. Downloadable on: www.ilo.org/public/english/ wcsdg/globali/biblio.pdf [visited 5 May 2004].

Hagen, Katherine A. 2003. The International Labour Organization: Can it deliver the social dimension of globalization? Friedrich Ebert Stiftung (Geneva Office), Dialogue on Globalization, Occasional Papers No. 11 (Oct.). Downloadable on: http://fes.globalization.think-visually.de/pubDriver/clients/fesDog/attachments/031001_01_Genf.pdf [visited 27 Apr. 2004].

Hart, Jeffrey A.; Prakash, Aseem. 1997a. "The decline of 'embedded liberalism' and the rearticulation of the Keynesian welfare state", in New Political Economy (Sheffield), Vol. 2 (March), pp. 65-78.

-; - .1997b. "Strategic trade and investment policies: Implications for the study of international political economy", in The World Economy (Oxford), Vol. 20, No. 4 (July), pp. 457-476.

Hayter, Susan; Reinecke, Gerhard; Torres, Raymond. 2001. South Africa. Studies on the Social Dimension of Globalization. Geneva, ILO.

Heltberg, Rasmus. 2002. The poverty elasticity of growth. WIDER Discussion Paper No. 2002/ 21 (Feb.). Helsinki, United Nations University/World Institute for Development Economics Research. Downloadable on: www.wider.unu.edu/publications/publications.htm [visited 25 May 2004].

Henry, Miriam; Lingard, Bob; Rizvi, Fazal; Taylor, Sandra. 2001. The OECD, globalisation and education policy. Oxford, Pergamon (for the IAU Press).

International Labour Office (ILO). 2004. A fair globalization: Creating opportunities for all. Report of the World Commission on the Social Dimension of Globalization. Geneva.

-. 2003. Fundamental rights at work and international labour standards. Geneva.

-. 1999. Decent work. Report of the Director-General to the International Labour Conference, 87th Session, 1999. Geneva.

International Monetary Fund (IMF). 2003a. World Economic Outlook 2003. Washington, DC.

-.2003b. International Financial Statistics 2003. Washington, DC.

-. 2000. World Economic Outlook: Asset prices and the business cycle, May 2000. Washington, DC.

Jacobs, Didier. 2002. "Democratizing global economic governance", in Jim Weaver, Didier Jacobs and Jamie Baker (eds.): After neoliberalism: Economic policies that work for the poor. Washington, DC, New Rules for Global Finance, pp. 45-63.

Kaplinsky, Raphael. 2001. "Globalisation and economic insecurity", in IDS Bulletin (Brighton), Vol. 32, No. 2 (Apr.), pp. 13-24.

Khan, Azizur Rahman; Griffin, Keith; Riskin, Carl. 1999. "Income distribution in urban China during the period of economic reform and globalization", in American Economic Review (Nashville, TN), Vol. 89, No. 2 (May), pp. 296-300.

Khor, Martin. 2001. Rethinking globalization: Critical issues and policy choices. New York, NY, Zed Books. Also downloadable on: www.unctad.org/en/docs/dp_147.en.pdf [visited 6 May 2004].

Kohl, Richard (ed.). 2003. Globalisation, poverty and inequality. Paris, Development Centre of the Organisation for Economic Co-operation and Development.

Köhler, Horst. 2003. The challenge of globalization and the role of the IMF. Address to the Annual Meeting of the Society for Economists and Management, held at Humboldt University, Berlin, 15 May. Downloadable on: www.imf.org/external/np/speeches/ 2003/051503.htm [visited 6 May 2004].

Lee, Eddy. 2000. "Globalization and employment: The new policy agenda”, in Development (London), Vol. 43, No. 2 (June), pp. 18-20.

-.1998. The Asian financial crisis: The challenge for social policy. Geneva, ILO.

Maskus, Keith E. 1997. Should core labor standards be imposed through trade policy? Policy Research Working Paper No. 1817 (Aug.). Washington, DC, World Bank. 
Masson, Paul R. 2001. Globalization: Facts and figures. IMF Policy Discussion Paper PDP/ 01/4. Washington, DC, International Monetary Fund (Nov.).

McCann, Gerard; McCloskey, Stephen (eds.). 2003. From the local to the global: Key issues in development studies. London and Sterling, VA, Pluto Press.

Memedovic, Olga; Kyvenhoeven, Arie; Molle, Willem T.A. (eds.). 1998. Globalization of labour markets: Challenges, adjustment and policy response in the EU and LDCs. Dordrecht, Boston and London, Kluwer Academic Publishers.

Milanovic, Branko. 2002. Can we discern the effect of globalization on income distribution? Evidence from household budget surveys. Policy Research Working Paper No. 2876 (Apr.). Washington, DC, World Bank. Downloadable on: http://econ.worldbank.org/ files/17877_wp2876.pdf [visited 6 May 2004].

Miller, Carol; Vivian, Jessica. 2002. Women's employment in the textile manufacturing sectors of Bangladesh and Morocco. Geneva, UNRISD in cooperation with UNDP.

Mittelman, James H. (ed.). 1996. Globalization: Critical reflection. Boulder, CO, Lynne Rienner.

Moghadam, Valentine M. 2001. "Gender and globalization: Female labor and women's mobilization", in Journal of World-Systems Research (Riverside, CA). Downloadable on: http://csf.colorado.edu/jwsr/archive/vol5/vol5_number2/v5n2_split/jwsr_v5n2_moghadam.pdf [visited 6 May 2004].

Murshed, S. Mansoob (ed.). 2002. Globalization, marginalization and development. London, Routledge.

-. 2000. Globalization, marginalization and development. Working Paper No. 175 (Feb.). Helsinki, United Nations University/World Institute for Development Economics Research.

Nayyar, Deepak. (ed.). 2002. Governing globalization: Issues and institutions. Oxford, Oxford University Press.

-. 2001. "Globalization: What does it mean for development?", in Jomo K.S. and Shyamala Nagaraj (eds.): Globalization versus development. Houndmills, Basingstoke and New York, NY, Palgrave, pp. 1-25.

Norton, Andy. 2000. Can there be a global standard for social policy? The 'social policy principles' as a test case. ODI Briefing Paper No. 2 (May). London, Overseas Development Institute.

-; Conlin, Sean. 2000. Globalisation processes and the implications for the development of global responses in the field of social policy. Background paper for the Department for International Development's White Paper on Eliminating world poverty: Making globalisation work for the poor. London, HMSO.

Ocampo, José Antonio; Martín, Juan (eds.). 2003. Globalization and development: A Latin American and Caribbean perspective. Palo Alto, CA, Stanford University Press.

Organisation for Economic Co-operation and Development (OECD). 1996. Trade, employment, and labour standards: A study of core workers' rights and international trade. Paris.

-.1995. Trade and labour standards: A review of the issues. Paris.

Oxfam America. 2002. Global finance hurts the poor: Analysis of the impact of North-South private capital flows on growth, inequality and poverty. Boston, MA, May.

Oxfam International. 2002. Rigged rules and double standards: Trade, globalisation, and the fight against poverty. Oxford.

Paratian, Rajendra; Torres, Raymond. 2001. Bangladesh. Studies on the Social Dimension of Globalization. Geneva, ILO.

Prasad, Eswar; Rogoff, Kenneth; Wei, Shang-Jin; Kose, M. Ayhan. 2003. Effects of financial globalization on developing countries: some empirical evidence. Washington, DC, International Monetary Fund (March). Downloadable on: www.imf.org/external/np/ res/docs/2003/031703.pdf [visited 6 May 2004].

Rama, Martín. 2003. Globalization and workers in developing countries. Policy Research Working Paper No. 2958 (Jan.). Washington, DC, World Bank. Downloadable on: http://econ.worldbank.org/files/23213_wps2958.pdf [visited 27 Apr. 2004]. 
Reinecke, Gerhard; Torres, Raymond. 2001. Chile. Studies on the Social Dimension of Globalization. Geneva, ILO.

Rodrik, Dani. 2001. The global governance of trade as if development really mattered. Background paper for the Trade and Sustainable Human Development Project, UNDP. New York, NY, UNDP.

-. 1997. "Sense and nonsense in the globalization debate", in Foreign Policy (Washington, DC) No. 107 (Summer), pp. 19-37.

-. 1996. "Labor standards in international trade: Do they matter and what to do about them", in Robert Z. Lawrence, Dani Rodrik, and John Whalley (eds.): Emerging agenda for global trade: High stakes for developing countries. Policy Essay No. 20. Washington, DC, Overseas Development Council.

Romero, Ana Teresa; Torres, Raymond. 2001. Switzerland. Studies on the Social Dimension of Globalization. Geneva, ILO.

Scheve, Kenneth F.; Slaughter, Matthew J. 2002. Economic insecurity and the globalization of production. NBER Working Paper No. 9339. Cambridge, MA, National Bureau of Economic Research. Downloadable on: www.nber.org/papers/w9339.pdf [visited 6 May 2004]..

Shorrocks, Anthony; van der Hoeven, Rolph (eds.). 2004. Growth, inequality and poverty: Prospects for pro-poor economic development. Oxford, Oxford University Press.

Siebert, Horst. (ed.). 2003. Global governance: An architecture for the world economy. Berlin and New York, Springer.

-. 1997. An institutional order for a globalizing world economy. Working Paper No. 807 (Apr.). Kiel, Institut für Weltwirtschaft, University of Kiel.

Singh, Ajit; Dhumale, Rahul. 2000. Globalization, technology, and income inequality: A critical analysis. Working Paper No. 210 (Dec.). Helsinki, United Nations University/ World Institute for Development Economics Research (UNU/WIDER). Downloadable on: www.wider.unu.edu/publications/wp210.pdf [visited 6 May 2004].

Solimano, Andrés. 2001. International migration and the global economic order: An overview. Policy Research Working Paper No. 2720 (Nov.). Washington, DC, World Bank, Development Research Group, Macroeconomics and Growth.

Srinivasan, T. N. 1994. "International labor standards once again!", in Bureau of International Labor Affairs (ed.): International labor standards and global economic integration: Proceedings of a symposium. Washington, DC, Bureau of International Labor Affairs, US Department of Labor.

Stalker, Peter. 2000. Workers without frontiers: The impact of globalization on international migration. Boulder, CO, Lynne Rienner Publishers/Geneva, ILO.

Stiglitz, Joseph E. 2003. The roaring nineties: A new history of the world's most prosperous decade. New York, NY, W.W. Norton \& Company.

-. 2002. "Employment, social justice and social well-being", in International Labour Review (Geneva), Vol. 141, No. 1-2, pp. 9-29.

Storm, Servaas; Naastepad, C.W.M. (eds.). 2001. Globalization and economic development: Essays in honour of J. George Waardenburg. Cheltenham, UK and Northampton, MA, Edward Elgar.

Torres, Raymond. 2001a. Towards a socially sustainable world economy: An analysis of the social pillars of globalization. Geneva, ILO.

-. 2001b. Republic of Korea. Studies on the Social Dimension of Globalization. Geneva, ILO.

-; Enzler, Christine; Reinecke, Gerhard; Romero, Ana Teresa. 2001. Poland. Studies on the Social Dimension of Globalization. Geneva, ILO.

Tzannatos, Zafiris. 1999. "Women and labor market changes in the global economy: Growth helps, inequalities hurt and public policy matters", in World Development (Oxford), Vol. 27, No. 3 (Mar.), pp. 551-569.

United Nations Conference on Trade and Development (UNCTAD). 1996. Globalization and liberalization: Effects of international economic relations on poverty. New York and Geneva, UNCTAD. 
van der Hoeven, Rolph. 2000. Labour markets and income inequality: What are the insights after the Washington Consensus? Working Paper No. 209. Helsinki, United Nations University/World Institute for Development Economics Research (UNU/WIDER). Downloadable on: www.wider.unu.edu/publications/publications.htm [visited 6 May 2004].

-; Taylor, Lance. 2000. "Structural adjustment, labour markets and employment: Some considerations for sensible people", in The Journal of Development Studies (London), Vol. 36, No. 4 (Apr.), pp. 57-65.

Weisbrot, Mark; Baker, Dean. 2002. The relative impact of trade liberalization on developing countries. Briefing Paper. Washington, DC, Center for Economic and Policy Research, June. Downloadable on: www.cepr.net/relative_impact_of_trade_liberal.htm. [visited 6 May 2004].

-; -; Kraev, Egor; Chen, Judy. 2001. The scorecard on globalization 1980-2000: Twenty years of diminished progress. Briefing Paper. Washington, DC, Center for Economic and Policy Research. Downloadable on: www.cepr.net/globalization/scorecard_on_globalization.htm [visited 6 May 2004].

_.; Naiman, Robert; Kim, Joyce. 2000. The emperor has no growth: Declining economic growth rates in the era of globalization. Briefing Paper. Washington, DC, Center for Economic and Policy Research. Downloadable on: www.cepr.net/IMF/ The_Emperor_Has_No_Growth.pdf [visited 6 May 2004].

White, Ben. 1996. "Globalization and the child labour problem", in Journal of International Development (Manchester), Vol. 8 (Nov.-Dec.), pp. 829-839.

Wolfensohn, James D. 2003. A new global balance: The challenge of leadership. Address to the Board of Governors, Dubai, United Arab Emirates, 23 Sep. 2003. Washington, DC, World Bank.

-. 2001. The challenges of globalization: The role of the World Bank. Address to the Bundestag, Berlin, 2 Apr. 2001. Washington, DC, World Bank.

Woolcock, Michael. 2001. Globalization, governance and civil society. Background paper to World Bank (2002). Downloadable on: http://econ.worldbank.org/prr/subpage.php?sp=2477 [visited 6 May 2004].

World Bank. 2003a. Global Development Finance, 2003. Washington, DC.

-.2003b. World Development Indicators 2003. Washington, DC.

-. 2002. Globalization, growth, and poverty: Building an inclusive world economy. Policy Research Report. New York, NY, Oxford University Press/Washington, DC, World Bank. Downloadable on: http://econ.worldbank.org/prr/subpage.php?sp=2477 [visited 26 July 2004]..

-.1995. World Development Report 1995. Washington, DC.

Yeates, Nicola. 2002. "Globalization and social policy: From global neoliberal hegemony to global political pluralism", in Global Social Policy (London), Vol. 2, No. 1 (Apr.), pp. 69-91.

-.2001. Globalization and social policy: From global neoliberal hegemony to global political pluralism. London, Sage Publication. 